\title{
Bartosz Swoboda \\ Zniewalająca siła ekfrazy \\ (rzecz o zmaganiach słowa i obrazu \\ w poglądach W.J.T. Mitchella)
}

ABSTRACT. Swoboda Bartosz, Zniewalająca siła ekfrazy (rzecz o zmaganiach słowa i obrazu $w$ poglądach W.J.T. Mitchella) [The captivating power of ekphrasis (on the struggle of word and picture in W.J.T. Mitchell's views)]. „Przestrzenie Teorii” 16. Poznań 2011, Adam Mickiewicz University Press, pp. 41-50. ISBN 978-83-232-2337-5. ISSN 1644-6763.

The article - in its first part titled The space of theory - brings a discussion and interpretation of the theoretical views concerning ekphrasis formulated by W.J.T. Mitchell in the essay Ekphrasis and the Other. The second part of the article - The space of practice and the space of picture aims to make an attempt at a practical application of Mitchell's theoretical postulates. To the reading in the spirit of his theoretical considerations is submitted the description of Jean-Baptiste Greuze's picture A Girl with a Dead Canary, which we find in Denis Diderot's Salon 1765.

[...] stowo w pewien sposób zamieszkuje przestrzeń obrazu.

Jacques Derrida, Prawda w malarstwie

\section{Przestrzeń teorii}

Trzy kolejne fazy, naznaczone - jak przekonuje W.J.T. Mitchell nieredukowalną ambiwalencją, konstytuują proces ekfrastycznej fascynacji ${ }^{1}$. Pierwsza z nich to ekfrastyczna obojętność [ekphrastic indifferen$c e$ ], której źródłem jest przekonanie, że ekfraza jest po prostu niemożliwa. Stanowisko to, ugruntowane na przeświadczeniu o nieprzezwyciężalnym dystansie między różnymi mediami - językiem i obrazem - oraz sposobami ich percepcji, staje się tłem dla prostej refutacji: deskrypcja [description] nigdy nie stanie się depikcją [depiction]:

Reprezentacja werbalna nie może uobecniać [represent] - czyli czynić obecnym [present] - swego obiektu w ten sam sposób, jak reprezentacja wizualna. Może ona odwoływać się do tego obiektu, opisywać go, przywoływać, ale nigdy nie może przedstawić jego wizualnej obecności, w taki sposób, w jaki czynią to obrazy [PT 152].

${ }^{1}$ Por. W.J.T. Mitchell, Ekphrasis and the Other, [w:] tenże, Picture Theory. Essays on Verbal and Visual Representation, Chicago-London 1994, s. 152-156. Kolejne cytaty z tej pozycji bezpośrednio w tekście głównym opatrzone skrótem $P T$. 
Drugą fazę wymienioną przez Mitchella stanowi ekfrastyczna nadzieja [ekphrastic hope], czyli fundament, na którym bazuje cała ekfrastyczna literatura: przekonanie o sile czytelniczej wyobraźni oraz nieograniczonej mocy poetyckiego języka, który pozwala w pełni uobecnić rzecz za pośrednictwem swoich znaków - przedstawiając pewien obiekt wyświadcza nam przysługę i momentalnie skrywa się za przedstawieniem, jest transparentny, ponieważ poświęca swoje własne istnienie na rzecz uobecnianego przedmiotu. Jednak u kresu realizacji tego pragnienia czyha ostatni wyznaczany przez Mitchella etap ekfrastycznej fascynacji - ekfrastyczny strach [ekphrastic fear], czyli moment oporu - którego kanoniczny przykład dostrzega Mitchell już w Laokoonie Gottholda E. Lessinga - przed ostatecznym uchyleniem granicy oddzielającej sztuki wizualne od werbalnych, sprzeciw wobec wolnej między nimi wymiany i unieważnienia różnicy pomiędzy właściwymi dla nich środkami wyrazu.

Skoro przezwyciężenie obcości staje się głównym warunkiem realizacji ekfrastycznej nadziei, a ekfrastyczny strach prowadzi do próby utrzymania opozycji między słowem i obrazem, to ekfraza nieuchronnie lokuje się $\mathrm{w}$ przestrzeni agonu2: mamy zatem poetycki język, który podporządkować musi sobie z jednej strony przedstawienie wizualne, natomiast z drugiej strony przedstawienie wizualne, które próbuje umknąć autorytatywnej władzy słowa (niezależnie od tego, czy jest to literacka ekfraza, czy dyskurs historii sztuki lub krytyki artystycznej). Ponadto, jak zauważa Mitchell, przedstawienie wizualne obsadzone zostaje przeważnie w klasycznej roli obcego, „pasywnego, wystawionego na widok i (zazwyczaj) niemego obiektu" [PT 157], podczas gdy tekst jest utożsamiany z emanacją „aktywnego, przemawiającego, oglądającego podmiotu” [PT 157] - ekfrastyczna praktyka sprowadza się de facto do tego, że obraz zostaje skolonizowany przez język, którego bezsporna dominacja sprawia, iż „reprezentacja wizualna nie może reprezentować sama siebie, musi być reprezentowana przez dyskurs" [PT 157].

Jednakże w wykładni Mitchella najbardziej interesujące wydaje się to, że wspomnianą przestrzeń agonu można $\mathrm{z}$ powodzeniem rozszerzyć poza podstawową dychotomię słowa i obrazu³: nierówny podział sił organizujący pole relacji między obrazem a tekstem może być projektowany

2 Propozycja Mitchella jest zatem radykalnym zwrotem w kierunku zupełnie przeciwnym niż ten wytyczany przez wygodne (i nadal cieszące się popularnością) formuły, takie jak „korespondencja sztuk”, „sztuki siostrzane” czy „wzajemne oświetlanie się sztuk” (poddawane zresztą przez Mitchella krytyce w artykule Going Too Far with the Sister Arts, [w:] Space, Time, Image, Sign, ed. by J. Heffernan, New York 1987).

${ }^{3}$ Podstawowe wyznaczniki tej dychotomii omawia Mitchell $\mathrm{w}$ tekście Word and Image, [w:] Critical Terms of Art History Writing, ed. by R.S. Nelson, R. Schiff, ChicagoLondon 2003. 
na różne konteksty angażujące antagonizm między reprezentacją werbalną i wizualną, na przykład na relacje społeczne, w których jedna strona dysponuje władzą obserwacji i przemawiania, druga natomiast zostaje uprzedmiotowiona, oddana nadzorowi spojrzenia i podporządkowana władaniu słowa. Relacja między społeczną rolą mężczyzny i kobiety, tak jak relacja między dziełem sztuki i widzem, to - zdaniem Mitchella przykłady obszarów zdeterminowanych przez identyczny układ sił: „Jeśli kobieta jest «ładna jak obrazek» (czyli niema i wystawiona na spojrzenie), nie jest zaskoczeniem, że obrazy będą traktowane jako żeńskie obiekty" [PT 163].

Wniosek autora Picture Theory możemy wzbogacić o interesujące ustalenia Ewy Kuryluk:

Pradawne utożsamienie obrazu z naturą, a słowa z kulturą - czytamy w pracy Weronika $i$ jej chusta - ma swoje daleko idące konsekwencje. Ponieważ naturę wiązano z kobiecością, a kulturę z męskością, obraz i słowo nabrały cech wywodzących się z doświadczeń płciowych, z przesądów erotycznych i metafor seksualnych ${ }^{4}$.

Ilekroć przedkładano - powiada dalej Kuryluk - język nad obraz, strumień słów kojarzono z takimi ideałami męskości, jak energia, intelekt, ruch i postęp, a słowom przeciwstawiano stereotypy kobiecości: bezwład, bierność i podporządkowanie cyklicznym prawom przyrody ${ }^{5}$.

Z kobiecością miały się łączyć - jak przekonuje Kuryluk, podając wiele sugestywnych przykładów - takie właściwości przedstawienia wizualnego, jak przestrzenność i materialność. Szczególnie kobiecy charakter materii - pojmowanej tak już od czasów Platona i Arystotelesa, ale również w wyobrażeniach o wiele bardziej archaicznych - pozwalał traktować ją jako plastyczną, w pełni uległą kształtującej władzy męskiej energii kulturowej ${ }^{6}$. Obraz jawi się zatem jako niemy, kobiecy obiekt wizualnej rozkoszy, nad którym męski głos (język) pragnie przejąć kontrolę, a relacja między słowem i obrazem wpisuje się w szereg opozycji binarnych, takich jak kultura/natura, męskość/kobiecość, forma/materia, dusza/ciało, czas/przestrzeń, które - pozornie spełniając rolę kategorii porządkujących dyskurs - w rzeczywistości są ukrytymi znakami władzy i wartości.

Podsumujmy: Mitchell lokuje ekfrazę w sferze reprezentacji, na której ściera się reprezentacja werbalna $\mathrm{z}$ reprezentacją wizualną, słowo z obrazem. Próbuje następnie uporządkować ten obszar, rzutując nań

4 E. Kuryluk, Weronika i jej chusta. Historia, symbolizm i struktura „prawdziwego" obrazu, Kraków 1998, s. 26-27.

5 Tamże, s. 29.

${ }^{6}$ Por. tamże, s. 27-29. 
stereotypową społeczną relację między płciami, i dochodzi do wniosku, że pole reprezentacji zdominowane jest przez literaturę - tak jak przestrzeń społeczna opanowana jest przez mężczyzn (czy też męskie zachowania) głównie ze względu na jej czysto językowy charakter, który pozwala jej korzystać z atrybutów tradycyjnie pojmowanej retoryki ${ }^{7}$. Nie sposób jednocześnie nie dostrzec, iż próbuje Mitchell wcisnąć ekfrazę w dosyć ciasny (i jednocześnie mocno zideologizowany) gorset.

Tropem wskazanym w eseju Ekphrasis and the Other podąża m.in. James A.W. Heffernan, w którego przekonaniu relacja między aktywnym męskim podmiotem i wystawionym na widok obrazem (szczególnie obrazem pięknej kobiety), z niesłychaną łatwością przechodzi ze sfery estetyki w sferę erotyki, a kontemplacja piękna sztuki przeobraża się w pragnienie zdobycia piękna przedstawionego w sztuce, czyli w pożądanie kobiety ${ }^{8}$. Jednak analizowane przez Heffernana teksty (m.in. Metamorfozy Owidiusza, Hero i Leander Marlowe'a, Gwatt na Lukrecji Szekspira) pozwalają mu, pozostając w ramach wyznaczonych przez refleksję Mitchella, spojrzeć na ekfrazę w nieco inny sposób. Przywoływane przez niego przykłady ekfrastycznych opisów dzieł sztuki przedstawiających (czy też jedynie symbolizujących) gwałt, wypowiadają się, jak przekonuje Heffernan, w imieniu skrzywdzonej kobiety. Zatem w takich przypadkach ekfraza przemawia głosem ofiary, pozwalając jej wypowiedzieć traumatyczne doświadczenie, które w innych okolicznościach pozostałoby niewypowiedziane: opisywane obrazy gwałtu „wynoszą na powierzchnię tekstu okrucieństwo przemocy seksualnej, tym samym podkopując retorykę uwodzenia” [MW 89]; „odmawiając współdziałania z retoryką uwodzenia, odmawiając zajęcia miejsca $\mathrm{w}$ narracji męskiego zaspokojenia, obraz piękna staje się obrazem piękna pogwałconego" [ $M W$ 90]. Podczas kiedy piękny obraz (czyli obraz piękna utożsamianego z kobietą) aktywuje retorykę pożądania, której monopolistą jest męski podmiot, obraz gwałtu

7 Nie znaczy to jednak, że niemożliwe są próby wprowadzenia obrazu jako pełnoprawnego uczestnika zmagań w tej retorycznej przestrzeni, czego świetny przykład dają prace Mieke Bal, ufundowane na przekonaniu, że „obrazy również są tekstami, ponieważ stanowią zbiór [network] praktyk dyskursywnych". M. Bal, Light in Painting. Disseminating Art History, [w:] Deconstruction and the Visual Arts. Art, Media, Architecture, ed. by P. Brunette, D. Wills, Cambridge 1994, s. 52. Autorka ta w praktyce wykorzystuje formułowane przez siebie przesłanki teoretyczne (określane przez nią mianem poetyki wizualnej) m.in. w interpretacjach malarstwa Rembrandta, zob. M. Bal, Reading Rembrandt. Beyond the Word-Image Opposition, Amsterdam 2006.

8 Por. J.A.W. Heffernan, Museum of Words. The Poetics of Ekphrasis from Homer to Ashbery, Chicago-London 2004, s. 78. Kolejne cytaty z tej pozycji bezpośrednio w tekście głównym opatrzone skrótem $M W$. 
otwiera drogę dla alternatywnego języka ekfrastycznego opisu, co Heffernan określa jako rewolucję obrazu przeciwko słowu:

W przeciwieństwie do zwerbalizowanego obrazu bezczasowego piękna [...], zwerbalizowany obraz gwałtu jest narracyjny i historia, którą opowiada lub przepowiada [...], jest historią opowiadającą dokładnie o tym, jak piękno zostaje pogwałcone oraz boleśnie zmuszone do aktu seksualnego [MW 89-90].

\section{Przestrzeń praktyki i przestrzeń obrazu}

Autor ekfrazy usytuowany jest pomiędzy opisywanym obiektem (dziełem sztuki) a czytelnikiem, „który (jeśli ekfrastyczna nadzieja zostanie spełniona) będzie mógł «ujrzeć» obiekt poprzez medium poetyckiego głosu” [PT 164], czyli, jak powiada Murray Krieger, „zobaczyć świat $\mathrm{w}$ słowach [see the world in the words]"9. Autor znajduje się więc w pozycji pomiędzy dwoma biegunami obcości: jednym $\mathrm{z}$ nich jest przedstawienie wizualne, natomiast na przeciwnym krańcu sytuuje się odbiorca tekstu. Ekfraza pośredniczy zatem w podwójnym tłumaczeniu i wymianie: przekładzie przedstawienia wizualnego na przedstawienie werbalne oraz zapośredniczonej przez tekst recepcyjnej rekonstrukcji pierwotnego przedstawienia wizualnego. Szereg wyjściowych relacji przedmiot/obrazpodmiot/tekst - w wyniku ich wzajemnego oddziaływania powstaje werbalna reprezentacja reprezentacji wizualnej ${ }^{10}$, czyli ekfraza - okazuje się, jak widzimy, układem trzypoziomowym - ménage à trois, jak pisze Mitchell - którego ostatnim ogniwem staje się czytelnik. Dopiero kiedy odbędzie on długą drogę powrotną, zrekonstruuje w swym umyśle dzieło sztuki, czyli zaspokoi pragnienie wizualnego obiektu (czy może raczej odnajdzie dla niego kompensacyjny substytut), dopiero wówczas spełnio-

9 M. Krieger, Ekphrasis. The Illusion of the Natural Sign, emblems by J. Krieger, Baltimore-London 1992, s. 11.

10 Tak można sformułować najprostszą definicję ekfrazy, por. PT 152; $M W 3$; G.F. Scott, The Rhetoric of Dilation. Ekphrasis and Ideology, „Word and Image” 1991 (Vol. 7), nr 4, s. 301; P. Wagner, Introduction: Ekphrasis, Iconotexts, and Intermediality - the State(s) of the Art(s), [w:] Icons - Texts - Iconotexts. Essays on Ekphrasis and Intermediality, ed. by P. Wagner, Berlin-New York 1996, s. 12. Definicja taka wydaje się funkcjonalna głównie dlatego, że obnaża podwójne dno ekfrastycznego opisu, który, powtórzmy raz jeszcze, będąc werbalną reprezentacją reprezentacji wizualnej, jest niczym innym jak reprezentacją reprezentacji. Inna, pokrewna, definicja sformułowana przez Davida Carriera: ekfraza to „werbalne prze-tworzenie wizualnej pracy plastycznej [verbal re-creation of the visual artwork]" (D. Carrier, Principles of Art History Writing, University Park (Penn.) 1997, s. 8), tylko pozornie wydaje się podobna, ponieważ nie odsłania już, w sposób równie oczywisty, reprezentacyjnej wielopoziomowości ekfrazy. 
na może zostać obietnica, jaką zdaje się przyrzekać ekfraza czytelnikowi, który zgadza się na formułowane przez nią reguły literackiej gry. Gry, dodajmy, w której już od samego początku poszczególni uczestnicy biorą udział na nierównych warunkach. Dzieło sztuki jest w owej grze stawką, a jednocześnie jej bezwolnym uczestnikiem, autor tekstu - główny dysponent reguł - przebiegłym pośrednikiem oferującym utopijną w gruncie rzeczy obietnicę dostępu do istoty dzieła sztuki, natomiast sam czytelnik jawi się w tym układzie jako figura nieco przewrotna: musi on zdawać sobie sprawę $\mathrm{z}$ tego, że dosięgnięcie dzieła sztuki poprzez tekst nie jest w żaden sposób możliwe, niemniej jednak - oczywiście tylko wtedy, kiedy przewagę zdobywa postawa oparta na ekfrastycznej nadziei - wstępuje do tej cokolwiek paradoksalnej gry ${ }^{11}$. Spróbujmy to prześledzić na przykładzie.

Salon 1765 roku rozpoczyna się, jak zwykle, 25 sierpnia, czyli w dniu świętego Ludwika. Jean-Baptiste Greuze - w owym czasie najpopularniejszy francuski malarz, przez paryską publiczność wręcz uwielbiany, jak zapewniają bracia Goncourtowie - prezentuje w Luwrze płótno zatytułowane Dziewczyna opłakujaca martwego ptaszka (Edynburg, National Gallery of Scotland). Relację z wystawy zdaje Denis Diderot, wówczas już stały komentator ekspozycji prac członków elitarnej Królewskiej Akademii Malarstwa i Rzeźby. W Salonie 1765 roku znajdujemy oczywiście opis dzieła Greuze'a12:

11 Przyjęcie optyki, w której głównym pragnieniem czytelnika jest maksymalne zbliżenie się do dzieła sztuki jednocześnie znacznie oddala te wszystkie wypadki, kiedy bardziej od przedmiotu opisu interesuje go sam opis, czyli tekst. Przypuszczać można, że zazwyczaj czytelnicze oczekiwania rozkładają się mniej więcej równomiernie: w tym samym stopniu czytelnik zainteresowany jest ekfrazą, co jej desygnatem.

${ }^{12}$ Ewentualna wątpliwość, czy opis Diderota możemy potraktować jako ekfrazę, wiąże się z poważnym teoretycznym dylematem: gdzie mianowicie zaczynają się, a gdzie kończą granice ekfrazy. Problem dotyczy zatem gatunkowego statusu owej reprezentacji werbalnej. Definicja ekfrazy przyjmowana przez Mitchella, Heffernana czy Scotta pozwala objąć swoim zasięgiem szeroki krąg tekstów, jednak równie wiele jest prób zawężenia zakresu ekfrazy do tekstów stricte literackich, czy wręcz jedynie poetyckich. W rodzimej refleksji teoretycznej pojawiła się propozycja Adama Dziadka, który zasugerował wykorzystanie typologii wprowadzonej przez Michaela Riffaterre'a, mianowicie podziału na ekfrazę literacką oraz ekfrazę krytyczną. Do pierwszej kategorii zaliczyć możemy utwory poetyckie (w całości lub tylko w pewnym stopniu poświęcone opisom dzieł sztuki) oraz opisowe fragmenty prozy narracyjnej. Drugą grupę stanowią teksty, powiedzmy, eseistyczne oraz prace z zakresu historii sztuki i krytyki artystycznej (por. A. Dziadek, Obrazy i wiersze. Z Zagadnień interferencji sztuk $w$ polskiej poezji wspótczesnej, Katowice 2004). W tym kontekście opis Diderota moglibyśmy z powodzeniem potraktować jako ekfrazę krytyczną (przez ten pryzmat teksty te czyta na przykład Bernadette Fort, zob. Ekphrasis as Art Criticism. Diderot and Fragonard's „Coresus and Callirhoe”, [w:] Icons - Texts - Iconotexts...), aczkolwiek wydaje się, że obecnie patrzymy na Salon jako na świadectwo zgoła literackie, tym 
Tytułowa postać ujęta jest en face, z głową podpartą lewą ręką, martwy ptak leży na brzegu klatki z obwisłą głową, rozpostartymi skrzydłami, łapkami w górę. Klatka jest więc jakby jego katafalkiem, ale jakże wdzięcznym, ileż uroku na przykład w tej gałązce, która oplata ją niczym śmiertelny wieniec! A sama dziewczyna - jaka przejęta! Jak naturalna w swym geście! Jaka ładna! Pięknie uczesana! Pełna wyrazu! Czujemy, że cierpi, że świat w tej chwili dla niej przestał istnieć. Śliczna jest także ręka, śliczne ramię; warto zwrócić uwagę na takie szczegóły, jak załamki skóry, jak miękkość, zaczerwienienie czubków palców w miejscu styku z głową. Chciałoby się ucałować tę rączkę, gdyby nie obawa urażenia dziewczęcych uczuć, zwłaszcza w takim momencie. Nawet nastrój jest uroczy: na przykład chusteczka zawiązana na szyi - jakże miękka i zwiewna. Patrząc na obraz, wołamy: „Rozkoszny!”"13.

W dalszej części opisu Diderot przekracza granice obrazu, wkracza w przestrzeń przedstawioną na płótnie, a właściwie to jego słowo wkracza $\mathrm{w}$ tę przestrzeń, ożywiając ją i całkowicie przejmując nad nią kontrolę, nie pozostawiając przy tym miejsca, w którym mógłby zrodzić się dialog. Jako że opis Diderota nie przewiduje możliwości dwugłosu, dziewczyna $\mathrm{z}$ obrazu nie może przemówić nawet na prawach prozopopei, mimo że zasypana zostaje gradem pytań, które mają na celu obnażenie prawdziwych przyczyn jej smutku14: „powiedz mi, skąd ta głęboka zaduma i melancholia? [...] Powiedz prawdę, mała, otwórz serce: czyżbyś naprawdę przeżywała tak silnie i głęboko - tylko śmierć ptaka?" [S 62]. Jest to chwyt bezwzględny, gdyż dziewczyna nie ma szansy na udzielenie jakichkolwiek wyjaśnień, ponieważ, jak już zostało powiedziane, autor Salonu nie buduje dialogu, w którym jeden z głosów podszywałby się pod wypowiedzi przepytywanej dziewczyny, pozostawiając $\mathrm{w}$ ten sposób, choćby złudne, wrażenie równoprawnego uczestnictwa. Miast tego Diderot sam odpowiada na zadawane przez siebie pytania, tym samym niedyskretnie odsłaniając prawdziwą, głęboką treść obrazu Greuze'a, zdejmując z dzieła woal melodramatycznej anegdoty:

Ach, zaczynam rozumieć: on cię kochał, przysięgał to, przysięgał od dawna. A tak przy tym cierpiał! Czy można patrzeć spokojnie na cierpienie ukochanej istoty?

Nie, nie, pozwól mi mówić dalej, nie zakrywaj mi ust. Dziś ra-

bardziej jeśli weźmiemy pod uwagę zdecydowanie literacką dyspozycję autora, który z opisów obrazów czyni właściwie miniaturowe opowiadania.

13 D. Diderot, Salon 1765 roku, przeł. J. Stadnicki, wybór, wstęp, oprac. A. Pieńkos, red. P. Juszkiewicz, Warszawa 2009, s. 62. Kolejne cytaty z tej pozycji bezpośrednio w tekście głównym opatrzone skrótem $S$.

14 Heffernan przyrównuje wręcz tę sytuację do inkwizycyjnego przesłuchania. J.A.W. Heffernan, Cultivating Picturacy. Visual Art and Verbal Interventions, Waco 2006, s. 53. 
no tak się nieszczęśliwie złożyło, że zjawił się, gdy mamy nie było w domu; był niezwykle piękny, wymowny, serdeczny, miły. Oczy mu płonęły, głos brzmiał jak sama prawda i trafiał wprost do serca. Padł na kolana, nie ma w tym nic złego, chwycił twoją rękę, łzy popłynęły po twoich ramionach. A mama wciąż nie wracała; to naprawdę nie twoja wina lecz jej [S 62-63, wyróżnienie moje - B.S.].

Cóż zatem? Diderot narratywizuje scenę przedstawioną na płótnie: dziewczyna pozwoliła się uwieść, zaufała głosowi mężczyzny („głos brzmiał jak sama prawda i trafiał wprost do serca”), który wyznawał jej szczere uczucie. Pod nieobecność opiekunów oddała się erotycznej rozkoszy. Rzec można, że nic strasznego jeszcze się nie stało, jednak, jak się okazuje, ptaszek - podarunek od kochanka - umiera, co widzimy właśnie na obrazie, i co ma sugerować, że dziewczyna została po prostu wykorzystana ${ }^{15}$. Dzięki interpretacyjnej błyskotliwości Diderota sentymentalna atmosfera płótna naznaczona zostaje piętnem erotycznego występku, a to nieuchronnie prowadzi do odczytywania dzieła w kategoriach moralizatorskich, i właśnie tak - w dużej mierze, jak przekonuje Bernadette Fort ${ }^{16}$, za sprawą autora Salonu - na obrazy francuskiego malarza patrzymy do dziś. Tak też patrzono na nie już w XIX wieku, kiedy sława Greuze'a przygasła i widziano w nim już tylko „malarza Cnoty”, który chce „pędzlem skłaniać do dobrych obyczajów”17.

Związek między Dziewczyna Greuze'a a opisem Diderota doskonale wpisuje się w relację ustaloną przez Mitchella. Czy dziewczyna mogłaby być bardziej piękna? Bardziej niema, bezwolna i bezbronna? Męski głos używając pewnego skrótu myślowego, mówimy: głos Diderota - dokonuje werbalnej interwencji w przestrzeń obrazu, wykorzystując przy tym

${ }^{15} \mathrm{~W}$ ikonografii tego okresu martwy ptak mógł być odczytywany jako sygnał utraty dziewictwa, zatem nie ma wątpliwości, że - tak jak przekonuje w swojej historii Diderot miało miejsce zbliżenie seksualne. Ponadto Diderot łączy symbolikę Dziewczyny opłakującej martwego ptaszka z Rozbitym zwierciadtem - obrazem Greuze'a wystawionym na Salonie z poprzedniego roku (por. M. Fried, Absorption and Theatricality. Painting and Beholder in the Age of Diderot, Berkley-Los Angeles 1980, s. 59). Oba dzieła, które łączył wspólny wątek znaczeniowy, miały spotkać się z podobnym niezrozumieniem ze strony odbiorców: „Czy nie sądzisz - pyta Diderot wyimaginowanego rozmówcę - że tłumaczenie łez dziewczyny z tego Salonu śmiercią ptaszka byłoby taką samą naiwnością, jak zadumy kobiet z Salonu poprzedniego - zbiciem lustra? Powtarzam: to dziecko opłakuje coś zupełnie innego" [S 64]. Otwarta jednak pozostaje kwestia, na ile obraz ten prefiguruje niespełnioną miłość, czy wręcz potwierdza przypuszczenie, że dziewczyna została wykorzystana i porzucona?

16 Por. B. Fort, Accessories of Desire. On Indecency in a Few Paintings by Jean-Baptiste Greuze, „Yale French Studies” 1998, 94, s. 146.

17 E. i J. de Goncourt, Sztuka XVIII wieku, wybór, przekł. wstęp i komentarz J. Guze, Warszawa 1981, s. 144. 
wszystkie dostępne mu atrybuty, na przykład sam projektuje pewien opór obrazu/dziewczyny („pozwól mi dalej mówić, nie zakrywaj mi ust”), ażeby go później bezlitośnie złamać18. Trudno się zatem zgodzić z twierdzeniem Alexandry Wettlaufer, która utrzymuje, że wkraczający w przestrzeń obrazu odbiorca nawiązuje „długą i szczegółową rozmowę z płaczącą dziewczyną”, a „dialog - przekonuje dalej Wettlaufer - zawsze był ważną zasadą kompozycyjną pisarstwa Diderota, pozwalającą mu na elastyczność w prezentacji dwóch stron każdego sporu i zjednywanie udziału odbiorcy w dochodzeniu do prawdy"19. Choć, jednocześnie, trzeba przyznać, że dialog istotnie wykorzystywany jest przez autora Salonu bardzo często, a wiele opisów obrazów wpisuje Diderot w ramy rozmowy, czy to zwracając się do zaprojektowanego w tekście rozmówcy, czy też bezpośrednio do czytelnika. No właśnie, czytelnika, odbiorcy ekfrazy, czyli ostatniego ogniwa trójstopniowej sekwencji, którą konstruuje Mitchell. Pierwotnie relacje Diderota ukazywały się w wydawanym przez Friedricha Melchiora von Grimma rękopiśmienniczym ekskluzywnym periodyku „Correspondance littéraire, philosophique et critique”. Krąg odbiorców pisma stanowiło kilkunastoosobowe grono najważniejszych postaci europejskiej sceny politycznej - monarchów i arystokratów, koneserów sztuki, którzy poznawali opis obrazu, zanim (o ile w ogóle) mieli okazję zobaczyć go na własne oczy. Wiedzeni chęcią poznania artystycznych nowości ze stolicy europejskiej sztuki zostawali niepostrzeżenie zwiedzeni, ponieważ ulegali sile sugestywnej Diderotowskiej ekfrazy, w której usłużny komentarz, szczegółowy, wierny wobec dzieła opis przegrywa z pragnieniem realizacji literackich ambicji oraz chęcią przeforsowania własnej interpretacji (niemniej nie jest to, jak próbowałem pokazać, interpretacja całkowicie ekscentryczna i pozbawiona podstaw ${ }^{20}$. Można by w tym miejscu przywołać celną uwagę Michała Pawła Markowskiego, który powiada, że ekfraza „wiąże się nierozerwalnie z przekona-

18 Można też, to już propozycja obarczona znacznie większym ryzykiem, spojrzeć na obraz przez pryzmat ustaleń Heffernana, wówczas dziewczyna występowałaby w roli ofiary. Wszak Diderot demaskuje retorykę uwodzenia, a jego opis zachowania dziewczyny może sugerować, że w postępowaniu adoratora, poza czułymi słowami, nie zabrakło także groźby, a może nawet przemocy.

19 A.K. Wettlaufer, In the Mind's Eye. The Visual Impulse in Diderot, Baudelaire and Ruskin, Amsterdam-New York 2003, s. 108.

20 Oczywiście zawsze może pojawić się opinia, że interpretacja ta mówi więcej o samym Diderocie niż o obrazie, choć autor Salonu 1765 roku w pierwszych zdaniach deklarował, że stara się opisywać poszczególne obrazy tak, aby „czytelnik z jaką taką wyobraźnią i smakiem mógł łatwo odtworzyć je sobie w myśli i porozmieszczać w niej poszczególne elementy w takim mniej więcej porządku, w jakim występują na płótnie” [S 20]. 
niem o wyższości słowa nad obrazem [...]: dyskurs o obrazie staje się ważniejszy od samego obrazu, gdyż słowa są doskonalszym medium przedstawienia, a nawet pretendują do statusu pozamedialnego"21.

W świetle teoretycznych rozważań Mitchella i czytanej w ich duchu ekfrastycznej praktyki Diderota otwarte pozostaje pytanie, czy obraz w ogóle może się wyzwolić spod władzy słowa, wszak aporetyczna mediacja ekfrazy - gest jednoczesnego oddalania i przybliżania przedmiotu opisu - tak głęboko zakorzeniona jest w tym sposobie pisania, że stanowi jego literacką esencję.

${ }^{21}$ M.P. Markowski, Ekphrasis. Uwagi bibliograficzne $z$ dołaczeniem krótkiego komentarza, „Pamiętnik Literacki” 1999, z. 2, s. 230. Na marginesie, łagodząc nieco minorowy ton ostatnich zdań, warto wspomnieć, że nie brakuje obecnie krytyków, którzy wieszczą kres takiej autorytatywnej, długowiecznej, bo obecnej już u samych antycznych źródeł, praktyki ekfrastycznej. Zdaniem Susan Harrow - by przywołać tylko jeden głos - rozpatrywanie ekfrazy w kontekście walki o dominację między słowem i obrazem (rzecz jasna z obrazem już w punkcie wyjścia skazanym na porażkę) przestaje być podejściem funkcjonalnym w obliczu najnowszej literatury, która umyślnie podkopuje swoją hegemonię w przestrzeni reprezentacji, świadoma własnych ograniczeń (głównie natury dyskursywnej) obmyśla „nową poetykę ekfrazy”. Ekfrazy, która wyrzeka się kolonizowania sztuki, skłonna jest raczej afirmować, niż redukować różnicę między reprezentacją wizualną i reprezentacją werbalną, a także kwestionuje tradycyjną wertykalną relację obraz - tekst, gdzie tekst funkcjonuje na zasadzie palimpsestu, który nadpisany nad obrazem ujawnia sam siebie kosztem dzieła. Por. S. Harrow, New Ekphrastic Poetics, „French Studies” 2010 (Vol. 64), nr 3, s. 258-259. 